\title{
Current status of cell-based therapies for respiratory virus infections: applicability to COVID-19
}

\author{
Maroun Khoury $\mathbb{1}^{1,2,6}$, Jimena Cuenca ${ }^{1,2}$, Fernanda F. Cruz ${ }^{3,4}$, \\ Fernando E. Figueroa (1) ${ }^{1,2}$, Patricia R.M. Rocco ${ }^{3,4}$ and Daniel J. Weiss ${ }^{5,6}$
}

Affiliations: 'Laboratory of Nano-Regenerative Medicine, Faculty of Medicine, Universidad de los Andes, Santiago, Chile. ${ }^{2}$ Cells for Cells and consorcio Regenero, Chilean Consortium for Regenerative Medicine, Santiago, Chile. ${ }^{3}$ Laboratory of Pulmonary Investigation, Carlos Chagas Filho Institute of Biophysics, Federal University of Rio de Janeiro, Rio de Janeiro, Brazil. "National Institute of Science and Technology for Regenerative Medicine, Rio de Janeiro, Brazil. ${ }^{5}$ Dept of Medicine, University of Vermont, Burlington, VT, USA. ${ }^{6} \mathrm{M}$. Khoury and D.J. Weiss contributed equally as lead authors of the study.

Correspondence: Maroun Khoury, Division of Nano-Regenerative Medicine, Faculty of Medicine, Universidad de los Andes, Av. La Plaza 2501, Las Condes, Chile. E-mail: mkhourydauandes.cl

@ERSpublications

It is imperative to better comprehend the rationale and underlying data that both support and refute effectiveness of MSCs in respiratory virus infections, and to define the targeted patient population and potential cell therapy approaches for COVID-19 https://bit.ly/2VbmYXs

Cite this article as: Khoury M, Cuenca J, Cruz FF, et al. Current status of cell-based therapies for respiratory virus infections: applicability to COVID-19. Eur Respir J 2020; 55: 2000858 [https://doi.org/ 10.1183/13993003.00858-2020].

ABSTRACT The severe respiratory consequences of the coronavirus disease 2019 (COVID-19) pandemic have prompted urgent need for novel therapies. Cell-based approaches, primarily using mesenchymal stem (stromal) cells (MSCs), have demonstrated safety and possible efficacy in patients with acute respiratory distress syndrome (ARDS), although they are not yet well studied in respiratory virus-induced ARDS. Limited pre-clinical data suggest that systemic MSC administration can significantly reduce respiratory virus (influenza strains $\mathrm{H} 5 \mathrm{~N} 1$ and $\mathrm{H} 9 \mathrm{~N} 2$ )-induced lung injury; however, there are no available data in models of coronavirus respiratory infection.

There is a rapidly increasing number of clinical investigations of cell-based therapy approaches for COVID-19. These utilise a range of different cell sources, doses, dosing strategies and targeted patient populations. To provide a rational strategy to maximise potential therapeutic use, it is critically important to understand the relevant pre-clinical studies and postulated mechanisms of MSC actions in respiratory virus-induced lung injuries. This review presents these, along with consideration of current clinical investigations. 


\section{Introduction}

The coronavirus disease 2019 (COVID-19) pandemic, originating in Wuhan, China, is rapidly and continuously spreading globally and can result in serious significant respiratory morbidity and mortality [1]. The responsible agent, severe acute respiratory syndrome coronavirus 2 (SARS-CoV-2), is an enveloped RNA virus of the Coronaviridae virus family. Human-to-human transmission occurs through respiratory droplets or contaminated surfaces [1]. The average incubation period is 5 days, but ranges from 1 to 14 days. Most patients present with mild respiratory tract infection, most commonly characterised by fever $(82 \%)$ and cough (81\%). Severe pneumonia and acute respiratory distress syndrome (ARDS) have been described in $14 \%$ of the reported cases, and the overall mortality is around $2 \%$ [2]. However, these numbers are evolving as the pandemic spreads, and depend on the country involved.

For COVID-19 patients who develop ARDS requiring intubation and mechanical ventilation, shock and multiple organ failure can also develop, although whether this is a direct consequence of viral infection or due to complications of critical illness is not yet clear. Current therapeutic approaches include aggressive standard supportive care and treatment of any other co-infections. Antiviral medications, including remdesivir, lopinavir-ritonavir, or lopinavir-ritonavir and interferon (IFN)- $\beta 1$, are under investigation but safety and potential efficacy remain to be determined. Remdesivir and IFN- $\beta 1 \beta$ appear to have superior antiviral activity to lopinavir and remdesivir in vitro for the Middle East respiratory syndrome (MERS) coronavirus but whether this is the case for SARS-CoV-2 remains to be determined [2]. The US Food and Drug Administration (FDA) has recently approved use of hydroxychloroquine in COVID-19 patients but the efficacy remains to be determined. Growing information also suggests that virus-induced cytokine storm in the lungs may drive severe pathogenesis and provide potential therapeutic targets, for example anti-interleukin (IL)-6 or anti-IL-1 approaches [3].

More recently, a growing number of clinical investigations of cell-based therapies, primarily involving mesenchymal stem (stromal) cells (MSCs) but also utilising MSC-derived conditioned media or extracellular vesicles and several other cell types, have been initiated in China for COVID-19 respiratory disease. As these encompass a wide range of approaches and targeted patient groups, it is imperative to better understand the rationale of the studies and the potential mechanisms of MSC actions towards respiratory viral infections. Recent pre-clinical data in models of respiratory virus infections and relevant related clinical studies of MSC administration in patients with ARDS can contribute to better definition of the patient population for whom potential MSC-based cell therapy approaches might be considered.

\section{Potential mechanisms of MSC actions in respiratory virus-induced lung injuries}

Following systemic administration, the majority of MSCs lodge in the pulmonary vascular bed through as yet unclear interactions with the capillary endothelial cells. Tracking studies using labelled MSCs demonstrate that most are cleared within $24-48 \mathrm{~h}$, although there can be longer persistence in injured or inflamed lungs [4]. The clearance mechanisms are still being elucidated but include apoptosis and subsequent efferocytosis and phagocytosis by resident inflammatory and immune cells, notably macrophages [5]. While lodged in the lungs, the MSCs are able to release a wide variety of soluble mediators including anti-inflammatory cytokines [6], antimicrobial peptides [7], angiogenic growth factors, and extracellular vesicles [8] (figure 1). Direct cell-cell transmission of mitochondria from MSCs to respiratory epithelial and immune cells [10] has also been described [11].

A growing literature demonstrates that the pattern of anti-inflammatory mediators released is specific for the inflammatory lung environment encountered and is mediated through differential activation of damage- and pathogen-associated molecular pathogen receptors expressed on MSC surfaces [12]. This includes Toll-like receptors (TLRs) that are activated by viral RNA (e.g. TLR3) (as in COVID-19) and viral unmethylated CpG-DNA (e.g. TLR9), leading to downstream cell signalling pathways resulting in MSC activation [13]. MSC-secreted angiopoietin-1 (Ang-1) and keratinocyte growth factor (KGF) contribute to the restoration of alveolar-capillary barriers disrupted as part of ARDS pathogenesis [14], while specific inhibitory microRNAs in extracellular vesicles are also described as mediating the protective effects of MSCs in pre-clinical models of bacterial or non-infectious acute lung injuries [15].

However, mediators responsible for ameliorating respiratory viral-induced lung injuries remain unclear. In animal models, influenza H9N2 viral infection increases serum and lung chemokines responsible for lung leukocyte infiltration, including granulocyte-macrophage colony-stimulating factor (GM-CSF), monocyte chemoattractant protein-1 (MCP-1), macrophage inflammatory protein-1 alpha (MIP-1 $\alpha$ ) and others, which are markedly reduced by intravenous administration of MSCs [16]. Increased levels of IFN- $\gamma$, typical of antiviral immune responses, alone or together with other pro-inflammatory cytokines, prompt MSC activation including the release of anti-inflammatory mediators. The importance of such IFN "licensing" of immunomodulating effects has been previously demonstrated in a model of graft versus host disease (GVHD), where the MSC-treated recipients of IFN- $\gamma^{-1-}$ T-cell grafts did not respond to cell therapy, 


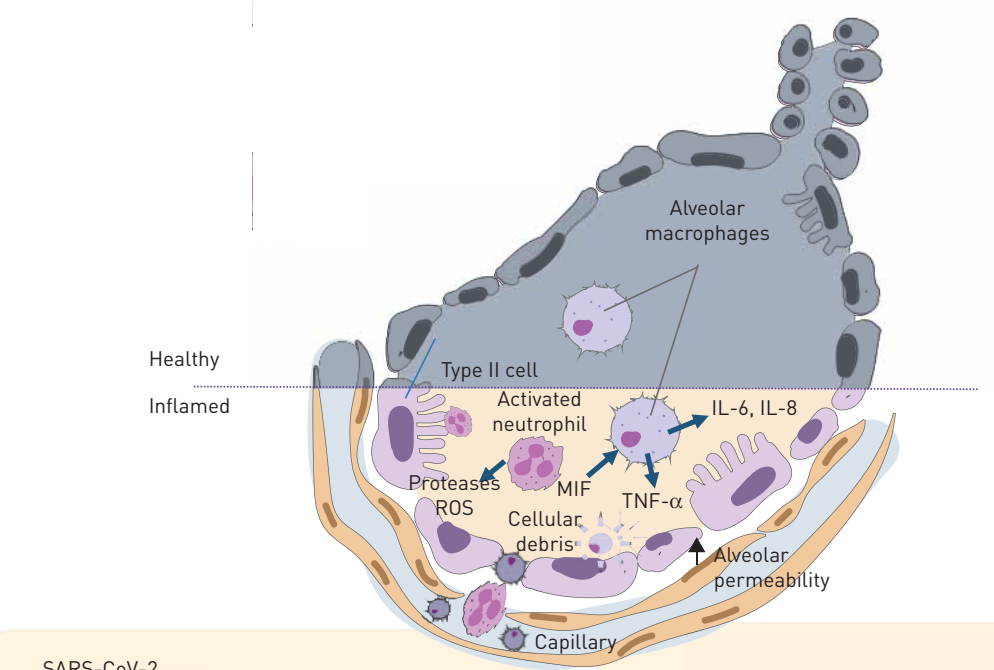

b)

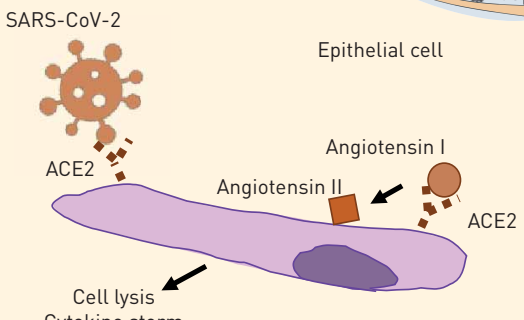

Cytokine storm

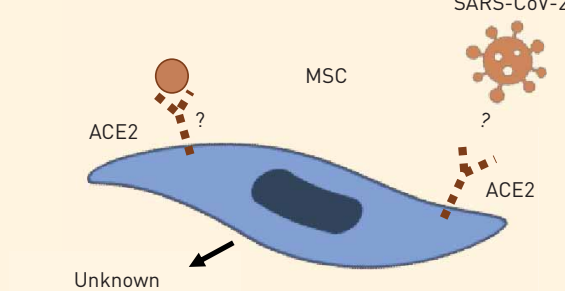

downstream effects

c)
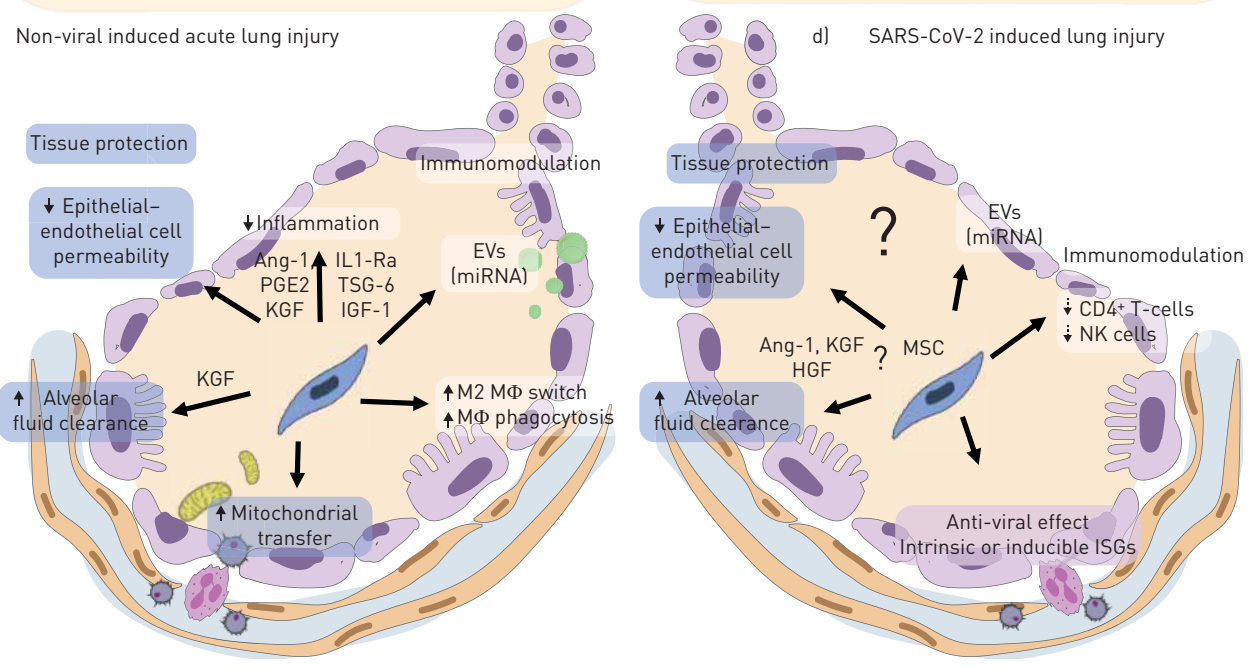

e)
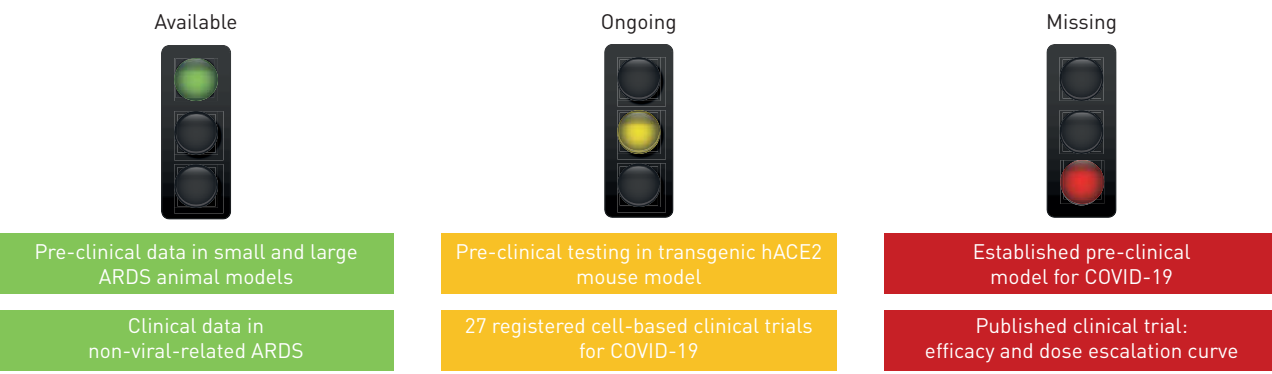

FIGURE 1 Potential therapeutic effects of mesenchymal stem (stromal) cells (MSCs) in respiratory lung injury are mediated by different mechanisms, including but not limited to secreted paracrine factors, extracellular vesicles (EVs) and possibly mitochondrial transfer, promoting tissue protection, immunomodulation and possibly viral resistance. a) Schematic of a healthy alveolus (top) and inflamed/oedematous alveolus (bottom) and mechanisms involved in acute respiratory distress syndrome (ARDS) pathogenesis. b) Schematic of severe acute respiratory syndrome coronavirus 2 (SARS-CoV-2) infecting a lung epithelial cell, with subsequent lysis and cytokine storm (left), and of potential MSC infection by SARS-CoV-2, with unknown downstream 
consequences (right). c) Some of the known mechanisms by which MSCs ameliorate non-viral acute lung injury. Adapted from LAFFEY and MATTHAY [9]. d) Limited information on mechanisms by which MSCs might ameliorate SARS-CoV-2 lung damage, based on limited pre-clinical data in influenza infection models. el Current state-of-the-art of cell-based therapy in coronavirus disease 2019 (COVID-19), based on pre-clinical and clinical studies. MIF: macrophage migration inhibitory factor; TNF: tumour necrosis factor; IL: interleukin; ROS: reactive oxygen species; ACE2: angiotensin-converting enzyme 2; Ang-1: angiopoietin-1; PGE2: prostaglandin E2; KGF: keratinocyte growth factor; IL1-Ra: IL-1 receptor antagonist; TSG-6:

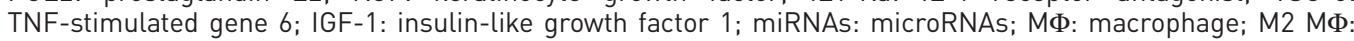
macrophage type 2; HGF: hepatocyte growth factor; NK cells: natural killer cells; ISGs: interferon-stimulated genes; hACE2: human ACE2.

evolving into fatal GVHD [17]. Unpublished data from COVID-19 patients in Italy suggest that high levels of IFN- $\gamma$ are found and thus may influence systemically administered MSCs (Massimo Dominici, University Hospital of Modena and Reggio Emilia, Modena, Italy; personal communication). However, "licensed" MSCs can also suppress alloantigen-induced T-cell functions in vitro, potentially compromising antiviral responses needed for disease control. For example, MSCs suppress lymphocyte proliferation in response to the activation of influenza-specific T-cells in vitro [18]. Umbilical cord-derived MSCs (UC-MSCs) have also been shown to inhibit the cytotoxicity of specific T-cells against H1N1 influenza virus in vitro [19], leading perhaps to prolonged infection in recipients. This is in contrast to reports where, for example, in models of cytomegalovirus (CMV) infection, MSCs exert differential effects on alloantigen and virus-specific T-cells that retain the ability to proliferate, produce IFN- $\gamma$ and kill CMV-infected cells in vitro [20].

An important question that remains to be resolved in respiratory virus infections is whether protective MSC actions are directly against viral infection, perhaps by stimulating antiviral T-cell actions, or whether they are due to overall anti-inflammatory actions that have been demonstrated in other models of acute lung injuries [9]. The latter may be particularly relevant for cytokine storm and it is likely that a combination of actions will be responsible.

\section{Effects of respiratory viruses on MSC actions}

MSCs are generally resistant to viral infection compared to their differentiated progeny [21]. In part this reflects intrinsic expression of IFN-stimulated genes (ISGs) that pre-empt viral infection [21]. MSC ISG expression includes, among others, IFITM family proteins, IFI6, ISG15, SAT1, PMAIP1, p21/CDKN1A and CCL2. Among these antiviral proteins, members of the IFITM family are unique as they prevent infection before a virus can traverse the lipid bilayer of the cell. These activities limit infection in cultured cells by many viruses, including dengue virus, Ebola virus, influenza A virus and severe acute respiratory syndrome (SARS) coronavirus [22]. Silencing of one of the most highly expressed ISGs in MSCs (p21/ CDKN1A) specifically increased their susceptibility to chikungunya virus (CHIKV), whereas knockdown of IFITM3 rendered MSCs susceptible to infection by a variety of viruses, including yellow fever virus and Zika virus [21].

Using RNA sequencing (GEO dataset GSE97987) and validation by quantitative reverse transcription PCR [21], we established a list of ISGs constitutively expressed by human embryonic stem cell-derived MSCs. Bioinformatic analysis of five independent GEO databases for expression changes following different pro-inflammatory cytokine stimulation of intrinsic ISGs in human MSCs (three bone marrow-derived MSCs (BM-MSCs), one UC-MSCs and one adipose tissue-derived MSCs (AD-MSCs), with the respective GEO datasets GSE68610, GSE77814, GSE46019, GSE46019 and GSE18662; figure 2) demonstrated that pro-inflammatory cytokines including IFN- $\gamma$ induced non-constitutive ISGs including MT1X, MT1G, SERPING1, SAT1, IFNAR2 and CD74, while significantly increasing the expression of constitutive antiviral genes such as IFI6, ISG15, CCL2, SAT1, PMAIP1 and IFITM1.

Hence, in the context of a respiratory viral infection, including COVID-19, MSCs might present two distinct antiviral mechanisms: constitutively elevated levels of MSC-specific ISGs to function as mediators of an antiviral protection, and a secondary response to IFN, leading to ISG induction and broad viral resistance. Conversely, MSCs could present a mix of intrinsic and inducible innate antiviral defences that could lead to therapeutic benefits in COVID-19 patients.

In contrast, some literature demonstrates that human BM-MSCs are permissive to avian influenza A (H5N1) infection, losing viability and immunoregulatory activities [16]. This can occur rapidly following exposure of uninfected MSCs [23], and virus-infected MSCs may thus not be functionally effective at stopping virus replication and lung inflammation [24-27]. BM-MSCs express influenza virus alpha-2,3 and alpha-2,6 sialic acid receptors on their cell surfaces and can support replication of both avian H1N1 and H9N5 influenza strains [24, 25]. Influenza-infected MSCs undergo cell lysis apoptosis within $18 \mathrm{~h}$ post exposure, with corresponding production of pro-inflammatory cytokines and chemokines [24] potentially 

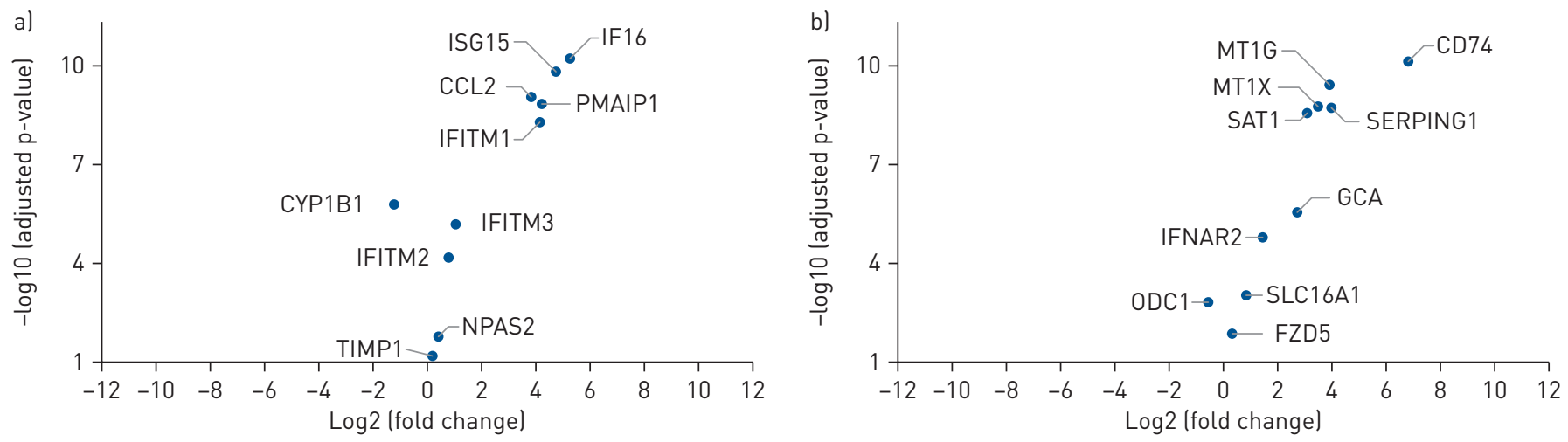

FIGURE 2 Representative volcano plot analysis of gene expression of the interferon-stimulated genes (ISGs) in human bone marrow-derived mesenchymal stem (stromal) cells (BM-MSCs) activated with pro-inflammatory cytokines (interleukin-1 $\beta$, tumour necrosis factor- $\alpha$ and interferon (IFN)- $\gamma$ ), versus control, in GEO dataset GSE68610. Gene expression analysis of al constitutive and b) non-constitutive ISGs. ISG15: ubiquitin-like protein; CCL2: C-C motif chemokine 2; IFI6: IFN- $\alpha$-inducible protein 6; PMAIP1: phorbol-12-myristate-13-acetate-induced protein 1; IFITM: IFN-induced transmembrane protein; CYP1B1: cytochrome p450 1b1; NPAS2: neuronal PAS domain-containing protein 2; TIMP-1: metalloproteinase inhibitor 1; MT1G/MT1X: metallothionein 1G/X: SERPING1: serpin family G member 1 (plasma protease C1 inhibitor); SAT1: sulfate anion transporter 1; GCA: grancalcin; IFNAR2: IFN- $\alpha / \beta$ receptor 2; SLC16A1: monocarboxylate transporter 1; ODC1: ornithine decarboxylase 1; FZD-5: Frizzled-5.

subverting their protective immunomodulatory properties [26]. The respiratory syncytial virus can also infect MSCs, modifying immune cell proliferation and activity [27]. As such, depending on the virus type and the level of expression or percentage of MSCs expressing the virus receptor, MSCs may get infected if infused into a patient with an ongoing respiratory virus infection. How this would affect potential beneficial effects remains to be determined.

\section{Do MSCs express ACE2, the functional receptor of SARS-CoV-2?}

Angiotensin-converting enzyme 2 (ACE2) has been reported to be the main host cell receptor for SARS-CoV-2 entry, and the virus uses the host cell serine protease TMPRSS2 for S protein priming [28]. ACE2 is highly expressed in respiratory epithelial cells, thus plays a crucial role in the entry of virus into these cells [29]. ACE2 was recently also demonstrated to be an ISG in nasal epithelial cells [30]. Hence, SARS-CoV-2 may exploit IFN-driven upregulation of ACE2, a key tissue-protective mediator during lung injury, to enhance infection. Conversely, ACE2 was reported to protect against non-viral lung injury by degrading the profibrotic peptide angiotensin II [31]. In vivo gene silencing of ACE2 enhances bleomycin-induced lung collagen deposition in mice, whereas systemic administration of purified ACE2 inhibits the fibrotic response [32]. Murine BM-MSCs overexpressing the ACE2 gene, following lentiviral vector transduction, offered additional anti-inflammatory and endothelial-protective effects against endotoxin-induced lung injury in mice $[33,34]$. However, there may be a downside to this if ACE2 overexpression results in infection and subsequent deleterious effects on the MSCs. As the level of gene expression is a key determinant of SARS-CoV-2 transmissibility [28], it is relevant to assess whether MSCs of any origin constitutively or inducibly express ACE2 or TMPRSS2.

\section{MSCs in respiratory virus-related lung injury: pre-clinical evidence}

There is a large body of literature demonstrating efficacy of either systemic or direct intratracheal MSC administration in pre-clinical models of respiratory diseases, including those involving acute lung injury induced by bacteria or bacterial products (endotoxins) or other means [35]. The models include rodents and large animals (pigs and sheep), as well as explanted human lungs. A range of approaches have been utilised for dose, dosing and MSC source, with MSCs from bone marrow, adipose tissue, umbilical cord, cord blood and placenta being investigated. A recent systematic review indicated that BM-MSCs and UC-MSCs were more effective than AD-MSCs in reducing mortality in pre-clinical acute lung injury models [36].

However, there are only a small number of pre-clinical studies investigating effects of MSC administration in pre-clinical models of respiratory virus infections. These have been further limited to influenza viruses, have produced conflicting results, and have not as yet directly addressed coronavirus respiratory infections (table 1). Notably, two earlier studies found MSCs not to be protective against influenza respiratory infections in mice. DARwish et al. [37] assessed the effects of a single systemic administration in immunocompetent mice of either syngeneic murine BM-MSCs or xenogeneic human BM-MSCs on lung injury induced by mouse-adapted $\mathrm{H} 1 \mathrm{~N} 1$ or swine-origin pandemic H1N1. Two different doses of MSCs $\left(2.5 \times 10^{5}\right.$ or $5 \times 10^{5}$ cells.mouse $\left.{ }^{-1}\right)$ were administered at different time-points after virus administration 
TABLE 1 Pre-clinical studies of MSCs in respiratory virus-related lung injury

\begin{tabular}{|c|c|c|c|c|c|c|c|}
\hline $\begin{array}{l}\text { First } \\
\text { author, } \\
\text { year } \\
\text { [ref.] }\end{array}$ & $\begin{array}{l}\text { Experimental model, route } \\
\text { of infection, type of virus }\end{array}$ & $\begin{array}{l}\text { MSC source, passage, number, } \\
\text { administration route, timing of } \\
\text { treatment }\end{array}$ & $\begin{array}{l}\text { Time of } \\
\text { outcome } \\
\text { analysis }\end{array}$ & $\begin{array}{l}\text { Adjuvant } \\
\text { therapy }\end{array}$ & Outcome & $\begin{array}{l}\text { Mechanisms of } \\
\text { action }\end{array}$ & $\begin{array}{l}\text { Control } \\
\text { group }\end{array}$ \\
\hline $\begin{array}{l}\text { DARWISH, } \\
2013 \\
\text { [37] }\end{array}$ & $\begin{array}{c}\text { C57BL/6 mice aged } \\
\text { 7-10 weeks, i.n. infection, } \\
\text { influenza A/PuertoRico/8/34 } \\
\text { (mouse- adapted H1N1) or } \\
\text { influenza A/Mexico/410 8/ } \\
2009 \text { (swine-origin pandemic } \\
\text { H1N1) }\end{array}$ & $\begin{array}{l}\text { Mouse BM-MSCs (P6-P9) or } \\
\text { human BM- MSCs (P3), } 2.5 \times 10^{5} \text { or } \\
5 \times 10^{5} \text { cells } \text { mouse }{ }^{-1} \text {, i.v. (tail vein), } \\
\text { single dose, days }-2,0,2 \text { or } 5 \text { post } \\
\text { infection }\end{array}$ & $\begin{array}{c}\text { Day } 7 \text { or } \\
\text { when } \\
\text { euthanasia } \\
\text { criteria were } \\
\text { met }\end{array}$ & $\begin{array}{l}\text { Oseltamivir } \\
2.5 \mathrm{mg} \cdot \mathrm{kg}^{-1} \\
\text { oral gavage, } \\
\text { once daily for } \\
5 \text { days }\end{array}$ & $\begin{array}{c}\text { Prophylactic and therapeutic } \\
\text { syngeneic and xenogeneic } \\
\text { administration of MSCs failed to } \\
\text { improve survival, failed to affect } \\
\text { weight loss, and failed to } \\
\text { decrease lung parenchyma } \\
\text { inflammation and BALF cell } \\
\text { counts }\end{array}$ & $\begin{array}{l}\text { Nonspecified } \\
\text { (soluble } \\
\text { mediators) }\end{array}$ & No \\
\hline $\begin{array}{l}\text { GotTs, } \\
2014 \\
{[38]}\end{array}$ & $\begin{array}{c}\text { C57BL/6 mice aged } \\
\text { 7-10 weeks, i.n. infection, } \\
\text { influenza A/Puerto Rico/8/34 } \\
\text { (mouse-adapted H1N1) }\end{array}$ & $\begin{array}{l}\text { Mouse BM-MSCs ( } \leqslant \text { P7) or human } \\
\text { BM-MSCs ( } \leqslant P 7 \text { ), } \\
5 \times 10^{5} \text { cells-mouse }{ }^{-1} \text {, i.v. } \\
\text { (retro-orbital injection) or i.t. (data } \\
\text { not shown); two doses: } 1 \text { ) days } 5 \\
\text { and } 6 \text { post infection, } 2 \text { ) days } 2 \text { and } \\
3 \text { post infection (data not shown) }\end{array}$ & $\begin{array}{c}\text { Days } 7,9 \text { or } \\
11\end{array}$ & No & $\begin{array}{l}\text { Mouse MSCs prevented } \\
\text { influenza-induced } \\
\text { thrombocytosis and caused a } \\
\text { modest reduction in lung viral } \\
\text { load on day 7; early (data not } \\
\text { shown) and late syngeneic and } \\
\text { xenogeneic i.v. administration of } \\
\text { MSCs failed to affect weight } \\
\text { loss, failed to decrease lung } \\
\text { water, failed to decrease BALF } \\
\text { inflammation, and failed to } \\
\text { improve lung histology; i.t. } \\
\text { administration increased } \\
\text { severity of model (data not } \\
\text { shown) }\end{array}$ & $\begin{array}{l}\text { Nonspecified } \\
\text { (soluble } \\
\text { mediators) }\end{array}$ & No \\
\hline $\begin{array}{l}\text { Chan, } \\
2016 \\
{[39]}\end{array}$ & $\begin{array}{l}\text { BALB/c mice aged } \\
\text { 6-8 weeks (young) or } \\
\text { 8-12 months (old), i.n. } \\
\text { infection, influenza A/Hong } \\
\text { Kong/486/1997(H5N1) }\end{array}$ & $\begin{array}{c}\text { Human BM-MSCs (passage not } \\
\text { mentioned), } 5 \times 10^{5} \text { cells mouse }{ }^{-1} \\
\text { i.v., single dose, day } 5 \text { post } \\
\text { infection }\end{array}$ & $\begin{array}{c}\text { Days } 7,10 \text { or } \\
18\end{array}$ & No & $\begin{array}{l}\text { In older mice, but not younger } \\
\text { mice, allogeneic MSCs } \\
\text { increased survival, reduced } \\
\text { weight loss, reduced lung } \\
\text { histopathological lesions, } \\
\text { increased M2 macrophages in } \\
\text { BALF, reduced lung } \\
\text { pro-inflammatory cytokines and } \\
\text { chemokines (MCP-1, MCP-3, } \\
\text { MIP-1 } \alpha \text {, RANTES, IL-4, IL-17, } \\
\text { TNF- } \alpha \text { ), but did not reduce lung } \\
\text { virus titres }\end{array}$ & $\begin{array}{l}\text { Paracrine soluble } \\
\text { mediators, } \\
\text { partially due to } \\
\text { Ang-1 and KGF } \\
\text { secretion }\end{array}$ & $\begin{array}{l}\text { NIH } 3 \text { T3 } \\
\text { mouse } \\
\text { embryo } \\
\text { fibroblasts }\end{array}$ \\
\hline
\end{tabular}




\begin{tabular}{|c|c|c|c|c|c|c|c|}
\hline $\begin{array}{l}\text { First } \\
\text { author, } \\
\text { year } \\
\text { [ref.] }\end{array}$ & $\begin{array}{l}\text { Experimental model, route } \\
\text { of infection, type of virus }\end{array}$ & $\begin{array}{l}\text { MSC source, passage, number, } \\
\text { administration route, timing of } \\
\text { treatment }\end{array}$ & $\begin{array}{l}\text { Time of } \\
\text { outcome } \\
\text { analysis }\end{array}$ & $\begin{array}{l}\text { Adjuvant } \\
\text { therapy }\end{array}$ & Outcome & $\begin{array}{l}\text { Mechanisms of } \\
\text { action }\end{array}$ & $\begin{array}{l}\text { Control } \\
\text { group }\end{array}$ \\
\hline $\begin{array}{l}\text { LI, } 2016 \\
{[16]}\end{array}$ & $\begin{array}{l}\text { C57BL/6 mice aged } \\
\text { 6-8 weeks, i.n. infection, } \\
\text { avian influenza virus Hong } \\
\text { Kong/2108/2003 (H9N2) }\end{array}$ & $\begin{array}{c}\text { Mouse BM-MSCs (P3-P10), } \\
1 \times 10^{5} \text { cells.mouse }{ }^{-1} \text {, i.v. (tail vein), } \\
\text { single dose, } 30 \text { min or day } 1 \text { post } \\
\text { infection }\end{array}$ & Day 3 & No & $\begin{array}{l}\text { Regardless of time of } \\
\text { administration, syngeneic MSCs } \\
\text { did not reduce lung virus } \\
\text { titration, increased survival rate, } \\
\text { decreased lung oedema, } \\
\text { decreased histological injury, } \\
\text { and improved gas exchange; } \\
\text { early and late administration } \\
\text { reduced BALF and serum } \\
\text { cytokines (IL-6 and TNF- } \alpha \text { ); } \\
\text { early administration reduced } \\
\text { BALF chemokine (GM-CSF), } \\
\text { reduced BALF and serum } \\
\text { chemokines and cytokines (MIG, } \\
\text { IL- } 1 \alpha, \text { IFN- } \gamma \text { ), and increased } \\
\text { anti-inflammatory cytokine } \\
\text { IL- } 10 \text { in BALF and serum }\end{array}$ & $\begin{array}{l}\text { Nonspecified } \\
\text { (soluble } \\
\text { mediators] }\end{array}$ & No \\
\hline $\begin{array}{l}\text { KHATRI, } \\
2018 \\
{[40]}\end{array}$ & $\begin{array}{l}\text { White Duroc crossbred pigs } \\
\text { aged } 8 \text { weeks, i.n. infection, } \\
\text { influenza virus swine/TX/98 } \\
\text { (H3N2) and swine/MN/08 } \\
\text { (H1N1) }\end{array}$ & $\begin{array}{l}\text { Pig BM-MSC extracellular vesicles } \\
\text { (P3-P5), } 80 \mu \mathrm{g} \cdot \mathrm{kg}^{-1} \text { body weight } \\
\text { (produced by } 10 \times 106 \mathrm{MSC} \text { ), i.t., } \\
\text { single dose, } 12 \mathrm{~h} \text { post infection }\end{array}$ & Days 1 or 3 & No & $\begin{array}{l}\text { BM-MSC-derived extracellular } \\
\text { vesicles decreased virus } \\
\text { shedding in nasal swabs, } \\
\text { reduced influenza virus } \\
\text { replication in the lungs, } \\
\text { prevented virus-induced } \\
\text { production of pro-inflammatory } \\
\text { cytokines (TNF- } \alpha \text {, CXCL-10), } \\
\text { and reduced histological injury } \\
\text { and lung oedema }\end{array}$ & $\begin{array}{l}\text { Nonspecified } \\
\text { (extracellular } \\
\text { vesicles) }\end{array}$ & No \\
\hline $\begin{array}{l}\text { Loy, } 2019 \\
\text { [41] }\end{array}$ & $\begin{array}{c}\text { BALB/c mice aged } \\
\text { 6-8 weeks, i.n. infection, } \\
\text { influenza A/Hong Kong/486/ } \\
1997 \text { (H5N1) }\end{array}$ & $\begin{array}{l}\text { Human UC-MSCs }(\leqslant P 7) \\
5 \times 10^{5} \text { cells } \text { mouse }{ }^{-1}, \text { i.v., single } \\
\text { dose, day } 5 \text { post infection }\end{array}$ & $\begin{array}{c}\text { Days } 7,10,14 \\
\text { or } 18\end{array}$ & No & $\begin{array}{c}\text { UC-MSCs failed to decrease } \\
\text { lung virus titration, failed to } \\
\text { increase survival rate, reduced } \\
\text { body weight loss, decreased } \\
\text { lung oedema, and decreased } \\
\text { BALF cytokines (IP-10, MCP-1, } \\
\text { RANTES, IL-1ß) }\end{array}$ & $\begin{array}{l}\text { Paracrine soluble } \\
\text { mediators, } \\
\text { partially due to } \\
\text { Ang-1 and HGF } \\
\text { secretion }\end{array}$ & $\begin{array}{l}\text { NIH } 3 \text { T3 } \\
\text { mouse } \\
\text { embryo } \\
\text { fibroblasts }\end{array}$ \\
\hline
\end{tabular}

MSCs: mesenchymal stem (stromal) cells; i.n.: intranasal; i.v.: intravenous; i.t.: intratracheal; BM: bone marrow-derived; UC: umbilical cord-derived; BALF: bronchoalveolar lavage fluid; MCP: monocyte chemoattractant; MIP: macrophage inflammatory protein; RANTES: regulated upon activation, normal T-cell expressed and presumably secreted; IL: interleukin; TNF: tumour necrosis factor; Ang-1: angiopoietin-1; KGF: keratinocyte growth factor; GM-CSF: granulocyte-macrophage colony-stimulating factor; MIG: monokine induced by interferon- $\gamma$; IFN: interferon; CXCL-10: C-X-C motif chemokine 10; IP-10: interferon $\gamma$-induced protein 10; HGF: hepatocyte growth factor. 
(days $-2,0,2$ and 5 post infection (p.i.)). Using survival and different measures of lung inflammation as outcome end-points on day 7 p.i., neither syngeneic nor xenogeneic MSC administration, either alone or as an adjuvant therapy with oseltamivir, was effective either when administered prophylactically prior to virus inoculation, or when therapeutically administered. Similarly, GotTs et al. [38] assessed the effect of both systemic and intratracheal administration of human and mouse MSCs $\left(5 \times 10^{5}\right.$ cells.mouse $\left.^{-1}\right)$, administered in two doses, either earlier (days 2 and 3 p.i.) or later (days 5 and 6 p.i.), in mouse-adapted H1N1-induced lung injury in immunocompetent mice. However, MSCs did not improve influenza-mediated lung injury, regardless of administration route.

In contrast, more recent studies have demonstrated protective effects of systemic MSC administration in rodent and pig models of influenza respiratory infections. CHAN et al. [39] found, through in vitro assays, that MSCs improved the dysregulated alveolar fluid clearance and protein permeability induced by $\mathrm{H} 5 \mathrm{~N} 1$ and H7N9 influenza viruses, in part by releasing soluble mediators that upregulated sodium and chloride transporters. Systemic administration of $5 \times 10^{5}$ human BM-MSCs per mouse on day 5 p.i. in immunocompetent mice aged 8-12 months infected with influenza A (H5N1) reduced virus-induced mortality (until day 18 p.i.), weight loss (days 6-10 p.i.), lung oedema (day 7 p.i.), bronchoalveolar lavage fluid (BALF) $\mathrm{CD}^{+} \mathrm{T}$-cells and natural killer (NK) cells (day 7 p.i.), lung histopathological lesions (day 18 p.i.), and pro-inflammatory cytokines and chemokines (day 7 p.i.), without reducing lung virus titres (days 7 and 10 p.i.). They further found that Ang-1 and KGF released by MSCs were important, but not enough to attenuate the effects of viral infection on alveolar fluid clearance and permeability. However, in young mice (aged 6-8 weeks), no effects were observed in mortality and body weight loss. Thus, the data suggest that systemic MSC administration may provide benefit in older patients who are at higher risk for severe pulmonary illness caused by H5N1. Why this was less effective in younger mice is not clear at present.

Li et al. [16] investigated the impact of a low dose $\left(10^{5}\right.$ cells.mouse $\left.{ }^{-1}\right)$ of murine BM-MSCs in avian influenza virus (H9N2)-induced lung injury in young immunocompetent mice. A single intravenous administration led, on day 3 p.i., to reduction in mortality, lung oedema and histological injury, as well as in BALF and serum chemokines and cytokines, and to improved gas exchange and levels of anti-inflammatory mediators, although it did not reduce lung virus titration when administered either $30 \mathrm{~min}$ or $24 \mathrm{~h}$ after infection induction. Differences between early and later administration of MSCs were only observed in some BALF and serum inflammatory mediators. Only early administration reduced BALF levels of GM-CSF, reduced BALF and serum monokine induced by IFN- $\gamma$ (MIG), IL- $1 \alpha$ and IFN- $\gamma$, and increased levels of BALF and serum IL-10. Both early and later administration led to reduction of BALF and serum IL- 6 and tumour necrosis factor- $\alpha$. This might reflect that early administration seems more geared towards prevention of cell infection and inflammation, rather than dealing with more clinically relevant sequelae of epithelial infection. Avian influenza virus infection can trigger a very intense pro-inflammatory response compared to other influenza viruses; thus, Li et al. [16] speculated that the beneficial effects might be a specific consequence of different pathogenic features, compared to swine-origin H1N1 infection.

Loy et al. [41] found that UC-MSCs were more effective than human BM-MSCs at restoring impaired alveolar fluid clearance and permeability, in in vitro airway epithelial cell models. These effects were partially mediated through MSC secretion of Ang-1 and hepatocyte growth factor. The authors subsequently compared administration of UC-MSCs to BM-MSCs $\left(5 \times 10^{5}\right.$ cells $\cdot$ mouse $\mathrm{e}^{-1}$, day 5 p.i. $)$ in experimental lung injury induced by influenza A (H5N1) infection in female immunocompetent mice aged 6-8 weeks. Despite failure to reduce virus titre and increase survival rate, a single dose of UC-MSCs decreased body weight loss (days 16 and 17 p.i.), lung oedema (days 10 and 14 p.i.) and inflammation (day 7 p.i.) in H5N1-induced lung injury.

MSC-derived extracellular vesicles have been demonstrated to have comparable results, and in some cases are more effective than MSCs themselves in ameliorating inflammation and injury in a range of pre-clinical lung injury models [42, 43]. KHAtri et al. [40] found that systemic administration of extracellular vesicles isolated from pig BM-MSCs was safe and reduced virus shedding in nasal swabs, influenza replication in the lungs, BALF pro-inflammatory cytokines and chemokines, and histopathological changes, when administered $12 \mathrm{~h}$ after viral inoculation in a mixed swine (H3N2, H1N1) and avian (H9N5, H7N2) influenza-induced pig lung injury model. These findings suggest systemic extracellular vesicle administration as a potential cell-free strategy for use in respiratory virus-induced lung injuries.

There are as yet no pre-clinical data investigating effects of MSC administration in models of coronavirus respiratory infection, mostly due to the lack of an established animal model. SARS-CoV-2 replication was observed in several non-human primates and in inbred strains of mice following intranasal infection, but these models failed to show clinical signs of pulmonary disease as seen in humans [44]. Mice transgenic 
for human ACE2, infected with SARS-CoV-2, demonstrated virus replication in the lungs, as well as interstitial pneumonia with lymphocyte and monocyte infiltration into the alveolar interstitium and accumulation of macrophages in alveolar spaces [45]. While this model requires further evaluation, it might facilitate the testing of therapeutics including cell-based therapies for COVID-19. Recently, a non-human primate model for SARS-CoV-2 was able to reflect the same clinical signs, viral replication and pathology observed in humans, with comparable levels of mortality, and might be a valuable model for further evaluation [46].

Overall, it remains unclear whether the varying results reflect the differing features of each approach, including differences in the host (age), in the MSCs (source, number, route of administration), and in the virus-specific inflammatory patterns. Infection of the administered MSCs by the viruses, particularly the avian influenza viruses, might explain the lack of effectiveness observed in some in vivo studies, but MSC infection after their administration in vivo has not yet been investigated. In order to bypass the impact of viruses on MSCs, extracellular vesicles might be an option for further studies. Clearly, further pre-clinical studies must be done to evaluate the infectiveness of MSCs by coronaviruses and the impact of MSCs in coronavirus-induced lung injury models.

\section{Clinical investigations of MSC administration in patients with coronavirus or other respiratory virus-induced lung injury}

Despite suggestive recent evidence of potential efficacy of MSC administration in pre-clinical models of influenza respiratory viral lung infections, there are limited published clinical data available. A recently published single-centre open-label pilot investigation from the YouAn Hospital in Beijing (China) administered BM-MSCs to seven patients with COVID-19 pneumonia with differing degrees of severity including one patient with critically severe disease requiring care in the intensive care unit (ICU) [47]. The MSCs were given as a single intravenous administration at a dose of $10^{6}$ cells $\cdot \mathrm{kg}^{-1}$ body weight in $100 \mathrm{~mL}$ saline at various times after initial symptomatic presentation. The MSCs were assessed by RNA sequencing for expression of ACE2 or TMPRSS2 prior to administration and each was found to be minimally expressed (in one out of 12500 cells and seven out of 12500 cells, respectively), although the RNA sequencing results were not validated for gene (quantitative reverse transcription PCR) or protein expression.

The seven patients were categorised as critically severe $(n=1)$, severe $(n=4)$ and common type $(n=2)$. Three additional patients classified as severe received placebo (vehicle) administration for comparison. Patients were followed for 14 days after MSC or placebo administration and a range of safety and efficacy end-points were assessed. No infusional toxicities, allergic reactions, secondary infections or severe attributable adverse events were observed, and patients, including the one categorised as critically severe, apparently demonstrated clinical improvements within 2-4 days after MSC administration. However, while detailed information is provided for the critically severe patient, there is a lack of corresponding information for the other six patients or for the three placebo patients. Analyses of viral titres, circulating pro- and anti-inflammatory mediators, and lymphocyte numbers and populations were presented in detail for the critically severe patient and to a lesser degree for the other patients.

More detailed information as to inclusion and exclusion criteria, timing of MSC administration relative to onset of disease, comorbidities, clinical course of each patient, and evaluation of inflammatory mediators and cell populations for both treated and placebo patients are needed to better determine potential MSC efficacy and mechanisms of action. Importantly, there is no discussion as to whether the approach be further investigated in only critically severe and/or severe patients or for the broader range of clinical presentations of COVID-19 respiratory infection.

A second recently published study evaluated MSC administration in patients with H7N9 influenza virus respiratory infections during the 2013-2014 outbreak in China [48]. In this study, 17 critically ill patients with H7N9-induced ARDS received multiple intravenous administrations of menstrual blood-derived cells $\left(10^{6}\right.$ cells per infusion in Plasmalyte) obtained from a single healthy donor and outcomes were compared to 44 comparably critically ill patients receiving standard antiviral and supportive therapies. Of the treated patients, three are described as receiving three separate infusions during early-stage infection, six patients received three infusions at late-stage infection and eight patients received four infusions at late-stage infection. However, no information is provided concerning the timing between infusions or whether the control patients received vehicle infusions. The MSC-treated and control patients were otherwise fairly well matched for comorbidities and degrees of multi-organ failure and for use of other supportive therapies, except for a higher incidence of shock in the MSC-treated group $(\mathrm{p}<0.03)$. No apparent infusional toxicities or serious adverse events were noted. Three patients in the MSC-treated group died ( $82.4 \%$ survival), whereas 24 in the control died (45.5\% survival). However, no details were provided on the deaths, including cause and timing related to either infusion or to overall clinical course, or on other 
standard assessments including ventilator-free days, ICU stay or hospital stay. Complete blood count and measures of renal, liver, cardiac, and coagulation functions were comparable, except for a higher circulating pro-calcitonin level in the control group, perhaps suggestive of secondary or co-bacterial infections, although no information on other infections was provided. The authors concluded that MSC administration is a viable approach for H7N9-induced ARDS and that this could be potentially applicable to use in COVID-19 patients.

These two studies, while suggestive, highlight a number of issues with respect to potential use of MSCs in coronavirus and other viral respiratory infections. These include but are not limited to source of MSCs, dose and dosing strategies, including the number and timing of administrations. These studies also highlight issues with conduct of clinical trials for respiratory diseases, including those in critically ill patients. Full information about inclusion and exclusion criteria, clinical course, comorbidities, co-infections and laboratory evaluations, including investigative mechanistic evaluations, must be provided in a comprehensive manner.

\section{Assessment of the ongoing cell-based clinical trials registered during the COVID-19 outbreak}

At the time of this review, the number of cell-based clinical investigations to explore the therapeutic potential of cell treatment for SARS-CoV-2 infected patients registered since late January 2020 on the US National Institutes of Health (NIH) ClinicalTrials.gov database and the Chinese Clinical Trial Registry (www.chictr.org.cn), also accessible from the World Health Organization International Clinical Trial Registry Platform (WHO-ICTRP), has reached 27 entries with a total of approximately 1287 patients considered for enrolment (table 2). There are three main interventions: MSCs ( $\mathrm{n}=17 ; 781$ patients), MSC derivatives (conditioned media or extracellular vesicles; $n=4 ; 176$ patients), or other cell sources $(n=6 ; 330$ patients). General common features of the investigations include: 1) systemic administration, jointly with or followed by the recommended conventional supportive treatments for severe or critical SARS-CoV-2 infection [49]; 2) age range 18-80 years with no sex restrictions; 3) follow-up for at least 3 months; and 4) clinical samples collected will be throat secretions and/or blood. For the MSC investigations, 10 out of 17 will utilise UC-MSCs, one out of 17 will utilise menstrual blood-origin MSCs, and six out of 17 do not disclose the MSC tissue source. Notably, no apparent MSCs of bone marrow origin are being utilised, despite the majority of pre-clinical investigations for non-viral-induced acute lung injuries having utilised BM-MSCs. There is little clarification of use of cryopreserved versus continuously cultured cells [5]. Only six out of 16 disclose the intended cell injection dose, among which only four are correlated with the patient body weight. The intravenous dosing range varies between 0.4 and $42 \times 10^{6} \mathrm{cells}^{\mathrm{k}} \cdot \mathrm{kg}^{-1}$. In comparison, the highest dose of MSCs used in the published literature for clinical trials in non-viral ARDS was $10 \times 10^{6}$ cells $\cdot \mathrm{kg}^{-1}$ (START trial) [50]. The dosing strategy ranges between a single dose and five doses, with an average frequency of every 2 days.

Four of the trials will utilise either MSC-derived conditioned media or extracellular vesicles. Two of these propose aerosol inhalation of MSC-derived extracellular vesicles, one from AD-MSCs, for which there is no pre-clinical supporting data. Six investigations will utilise other cells, including umbilical cord blood-derived mononuclear cells, cytotoxic T-cells, dendritic cells, NK cells, cord blood stem cells and cytokine-induced killer cells, of which only the latter investigation describes dosing and frequency of injections. As best as we can ascertain, there are no apparent pre-clinical data to support the rationale for any of these approaches.

\section{Ethical issues for considering cell-based approaches for respiratory virus infections}

Activities of healthcare providers and researchers during an infectious disease outbreak, including clinical trials, are aimed towards finding rapid and effective responses for the treatment of infected patients. These actions need to occur under appropriate ethical guidelines. The World Health Organization has guidelines that embed ethical approaches and considerations within the integrated global alert and response system for epidemics and other public health emergencies [51]. These are all applicable to cell-based clinical investigations and include assurance that these are scientifically valid and that potential risks are reasonable in relation to anticipated benefits. With respect to safety of MSC administration in critically ill patients, including those with ARDS resulting from other aetiologies, no significant issues have been described in published articles to date [51]. With respect to efficacy, there is equipoise at present, as only one as yet unpublished exploratory trial of MSC administration has demonstrated beneficial outcomes [52].

It is also imperative that the clinical investigations be conducted in a transparent manner according to established precedents for clinical investigations of potential new therapies for critical illnesses [53]. This includes recognised end-points, including but not limited to overall mortality, length of ICU and hospital 
TABLE 2 Cell-based clinical trials using MSCs, MSC derivatives and other cells

\begin{tabular}{|c|c|c|c|c|c|c|}
\hline $\begin{array}{l}\text { Registration date } \\
\text { and execution } \\
\text { date range }\end{array}$ & $\begin{array}{l}\text { Study phase } \\
\text { and } \\
\text { recruitment }\end{array}$ & ID and URL & Title & Cell type & $\begin{array}{c}\text { Total } \\
\text { participants } \\
\mathrm{n}\end{array}$ & Intervention or treatment \\
\hline
\end{tabular}

DD-MM-YYYY status

Clinical trials based on MSC

1 14-02-2020

$20-02-2020$ to

20-02-2021

2 14-02-2020;

$20-02-2020$ to

20-02-2021

Not recruiting

ChiCTR2000029816

ttp://www.chictr.org

$\mathrm{cn} /$ showproj.aspx?

proj=49389

ChiCTR2000029817;

http://www.chictr.org.

$\mathrm{cn} / \mathrm{showproj.aspx?}$

proj $=49384$

Not recruiting

3 07-02-2020

$15-01-2020$ to

31-12-2022

0

Recruiting

ChiCTR2000029606;

http://www.chictr.org.

$\mathrm{cn} /$ showproj.aspx?

proj $=49146$

Clinical study for human menstrua

blood-derived stem cells in the

treatment of acute novel

coronavirus pneumonia (COVID-19)

$07-02-2020$

$06-02-2020$ to

30-09-2020

Recruiting

NCT://clinicalti

gov/show/NCT04269525

Umbilical cord (UC)-derived mesenchymal stem cells (MSCs)

treatment for the 2019-novel

coronavirus (nCOV) pneumonia

A prospective, single-blind,

ChiCTR2000029580;

http://www.chictr.org.

$\mathrm{cn} /$ showproj.aspx?

proj $=49088$

ruxolitinib combined with
A prospective, single-blind,

mesenchymal stem cell infusion in

the treatment of patients with severe

2019-nCoV pneumonia (novel

coronavirus pneumonia, NCP)
UCB-MSCs;

UCB-NK cells

$\mathrm{K}$ cells and

UCB-MSCs

Control group: conventional treatment NK cells $\left(>5 \times 10^{9}\right)$ and MSCs $\left(>5 \times 10^{9}\right)$, i.v. infusion once every 2 days for a total of 5 times

Conventional dose group: conventional dose NK cells $\left(>3 \times 10^{9}\right)$ and MSCs

$\left(>3 \times 10^{9}\right)$, i.v. infusion once every 2 days for a total of 3 times

Preventive dose group: preventive dose NK cells $\left(>3 \times 10^{9}\right)$ and MSCs $\left(>3 \times 10^{9}\right)$, i.v.

infusion once every week for a total of

time

MenSCs

Experimental group A:

Conventional treatment followed by i.v. infusion of MenSCs

Control group A: conventional treatment Experimental group B:

1: Artificial liver therapy + conventional treatment

2: Artificial liver therapy followed by i.v. infusion of MenSCs + conventional treatment

Control group B: conventional treatment

Experimental group: UC-MSCs $3.3 \times 10^{7}$ cells per $50 \mathrm{~mL}$ per bag, 3 bags each time; UC-MSCs will be infused i.v. on the $1 \mathrm{st}, 3 \mathrm{rd}, 5$ th and 7 th days after enrolment, once each day

Control group: none specified

Experimental group: ruxolitinib combined with MSCs

Control group: routine treatment 


\begin{tabular}{|c|c|c|c|c|c|c|c|}
\hline & $\begin{array}{l}\text { Registration date } \\
\text { and execution } \\
\text { date range } \\
\text { DD-MM-YYYY }\end{array}$ & $\begin{array}{l}\text { Study phase } \\
\text { and } \\
\text { recruitment } \\
\text { status }\end{array}$ & ID and URL & Title & Cell type & $\begin{array}{l}\text { Total } \\
\text { participants } \\
\mathbf{n}\end{array}$ & Intervention or treatment \\
\hline 6 & $\begin{array}{l}27-01-2020 \\
21-01-2020 \text { to } \\
31-12-2021\end{array}$ & $\begin{array}{c}1 \\
\text { Recruiting }\end{array}$ & $\begin{array}{c}\text { NCT04252118; } \\
\text { https://clinicaltrials. } \\
\text { gov/show/NCT04252118 }\end{array}$ & $\begin{array}{l}\text { Mesenchymal stem cell treatment } \\
\text { for pneumonia patients infected } \\
\text { with } 2019 \text { novel coronavirus }\end{array}$ & MSCs & 20 & $\begin{array}{l}\text { Experimental group: } 3.0 \times 10^{7} \text { MSCs i.v. at } \\
\text { days } 0,3 \text { and } 6 \\
\text { Control group: none specified }\end{array}$ \\
\hline 7 & $\begin{array}{l}14-02-2020 \\
16-02-2020 \text { to } \\
15-02-2022\end{array}$ & $\begin{array}{c}\text { NA } \\
\text { Not recruiting }\end{array}$ & $\begin{array}{l}\text { NCT04273646; } \\
\text { https://clinicaltrials. } \\
\text { gov/ct2/show/ } \\
\text { NCT04273646 }\end{array}$ & $\begin{array}{l}\text { Study of human umbilical cord } \\
\text { mesenchymal stem cells in the } \\
\text { treatment of novel coronavirus } \\
\text { severe pneumonia }\end{array}$ & UC-MSCs & 48 & $\begin{array}{l}\text { Experimental group: } 4 \text { times of UC-MSCs, } \\
0.5 \times 10^{6} \mathrm{UC}-\mathrm{MSCs} \cdot \mathrm{kg}^{-1} \text { body weight } i . v \text {. at } \\
\text { days } 1,3,5 \text { and } 7 \\
\text { Control group: none specified }\end{array}$ \\
\hline 8 & $\begin{array}{l}28-02-2020 \\
19-02-2020 \text { to } \\
20-02-2021\end{array}$ & $\begin{array}{c}1 \\
\text { Recruiting }\end{array}$ & $\begin{array}{l}\text { ChiCTR2000030300; } \\
\text { http://www.chictr.org. } \\
\text { cn/showprojen.aspx? } \\
\text { proj }=50022\end{array}$ & $\begin{array}{l}\text { Umbilical cord mesenchymal stem } \\
\text { cells (hucMSCs) in the treatment of } \\
\text { high risk novel coronavirus } \\
\text { pneumonia (COVID-19) patients }\end{array}$ & UC-MSCs & 9 & $\begin{array}{l}\text { Experimental group: MSCs } \\
\text { Control group: none specified }\end{array}$ \\
\hline 9 & $\begin{array}{l}26-02-2020 \\
14-02-2020 \text { to } \\
31-05-2020\end{array}$ & $\begin{array}{l}\text { NA } \\
\text { Not recruiting }\end{array}$ & $\begin{array}{l}\text { ChiCTR2000030224; } \\
\text { http://www.chictr.org. } \\
\text { cn/showprojen.aspx? } \\
\text { proj }=49968\end{array}$ & $\begin{array}{l}\text { Clinical study of mesenchymal stem } \\
\text { cells in treating severe novel } \\
\text { coronavirus pneumonia (COVID-19) }\end{array}$ & MSCs & 32 & $\begin{array}{l}\text { Experimental group 1: critical group, } \\
\text { intervention, injecting MSCs } \\
\text { Experimental group 2: severe group, } \\
\text { intervention, injecting MSCs } \\
\text { Control group 3: control of the critical } \\
\text { group, intervention, injecting normal } \\
\text { saline } \\
\text { Control group 4: control of the severe } \\
\text { group, intervention, injecting normal } \\
\text { saline }\end{array}$ \\
\hline 10 & $\begin{array}{l}24-02-2020 \\
17-02-2020 \text { to } \\
17-04-2020\end{array}$ & $\begin{array}{c}0 \\
\text { Not recruiting }\end{array}$ & $\begin{array}{l}\text { ChiCTR2000030173; } \\
\text { http://www.chictr.org. } \\
\text { cn/showprojen.aspx? } \\
\text { proj= }=49229\end{array}$ & $\begin{array}{l}\text { Key techniques of umbilical cord } \\
\text { mesenchymal stem cells for the } \\
\text { treatment of novel coronavirus } \\
\text { pneumonia (COVID-19) and clinical } \\
\text { application demonstration }\end{array}$ & UC- MSCs & 60 & $\begin{array}{l}\text { Experimental group: UC-MSCs } \\
\text { Control group: Conventional treatment }\end{array}$ \\
\hline 11 & $\begin{array}{l}24-02-2020 \\
24-02-2020 \text { to } \\
31-05-2020\end{array}$ & $\begin{array}{c}2 \\
\text { Not recruiting }\end{array}$ & $\begin{array}{l}\text { ChiCTR2000030138; } \\
\text { http://www.chictr.org. } \\
\text { cn/showproj.aspx? } \\
\text { proj=50004 }\end{array}$ & $\begin{array}{l}\text { Clinical trial for human } \\
\text { mesenchymal stem cells in the } \\
\text { treatment of severe novel } \\
\text { coronavirus pneumonia (COVID-19) }\end{array}$ & UC-MSCs & 60 & $\begin{array}{l}\text { Experimental group: i.v. injection of } \\
\text { UC-MSCs } \\
\text { Control group: routine treatment + placebo }\end{array}$ \\
\hline 12 & $\begin{array}{l}23-02-2020 \\
01-02-2020 \text { to } \\
31-08-2020\end{array}$ & $\begin{array}{c}\text { NA } \\
\text { Recruiting }\end{array}$ & $\begin{array}{l}\text { ChiCTR2000030116; } \\
\text { http://www.chictr.org. } \\
\text { cn/showproj.aspx? } \\
\text { proj=49901 }\end{array}$ & $\begin{array}{l}\text { Safety and effectiveness of human } \\
\text { umbilical cord mesenchymal stem } \\
\text { cells in the treatment of acute } \\
\text { respiratory distress syndrome of } \\
\text { severe novel coronavirus pneumonia } \\
\text { (COVID-19) }\end{array}$ & UC-MSCs & 16 & $\begin{array}{l}\text { Experimental group: different stem cell } \\
\text { doses } \\
\text { Control group: none specified }\end{array}$ \\
\hline
\end{tabular}




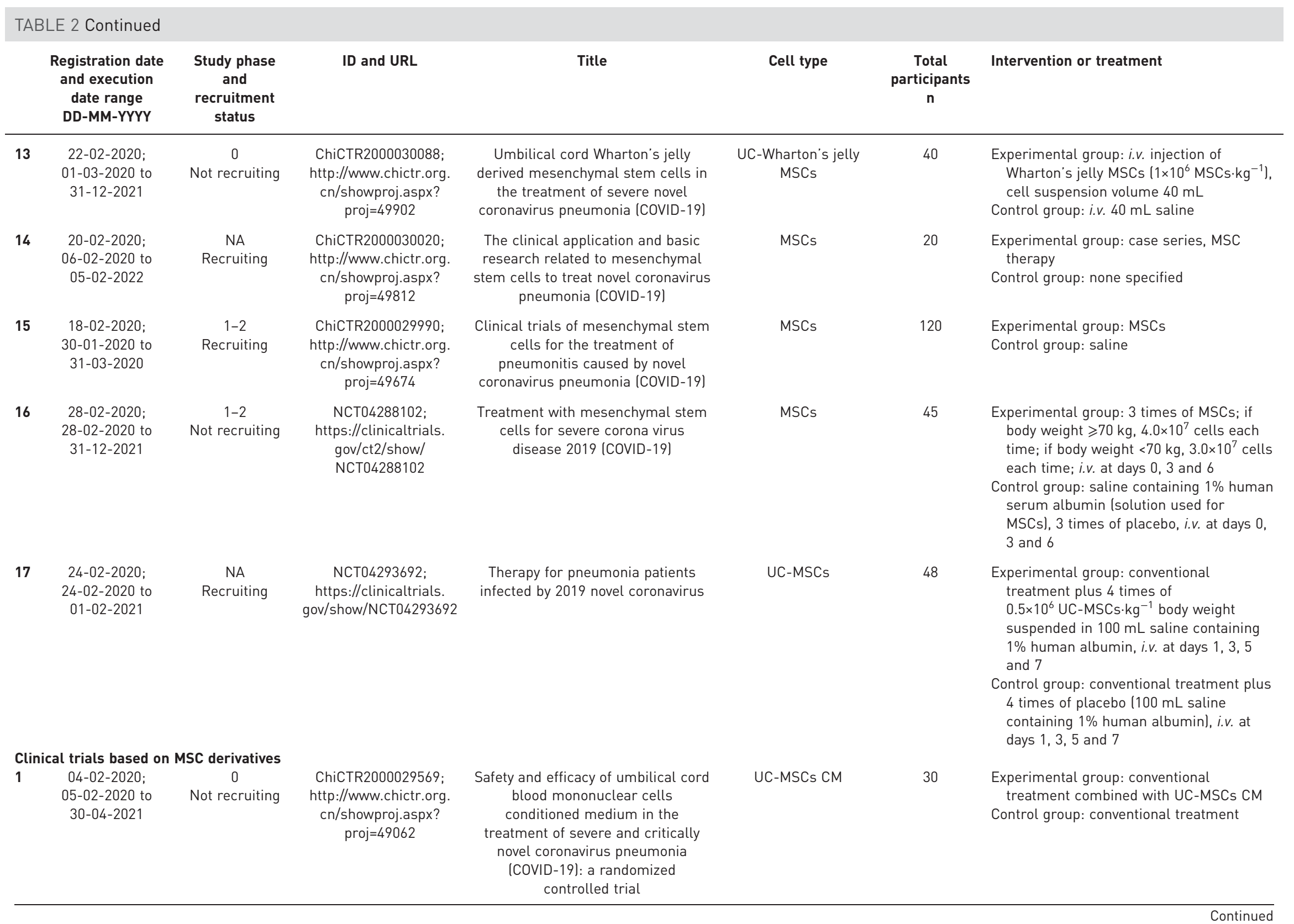




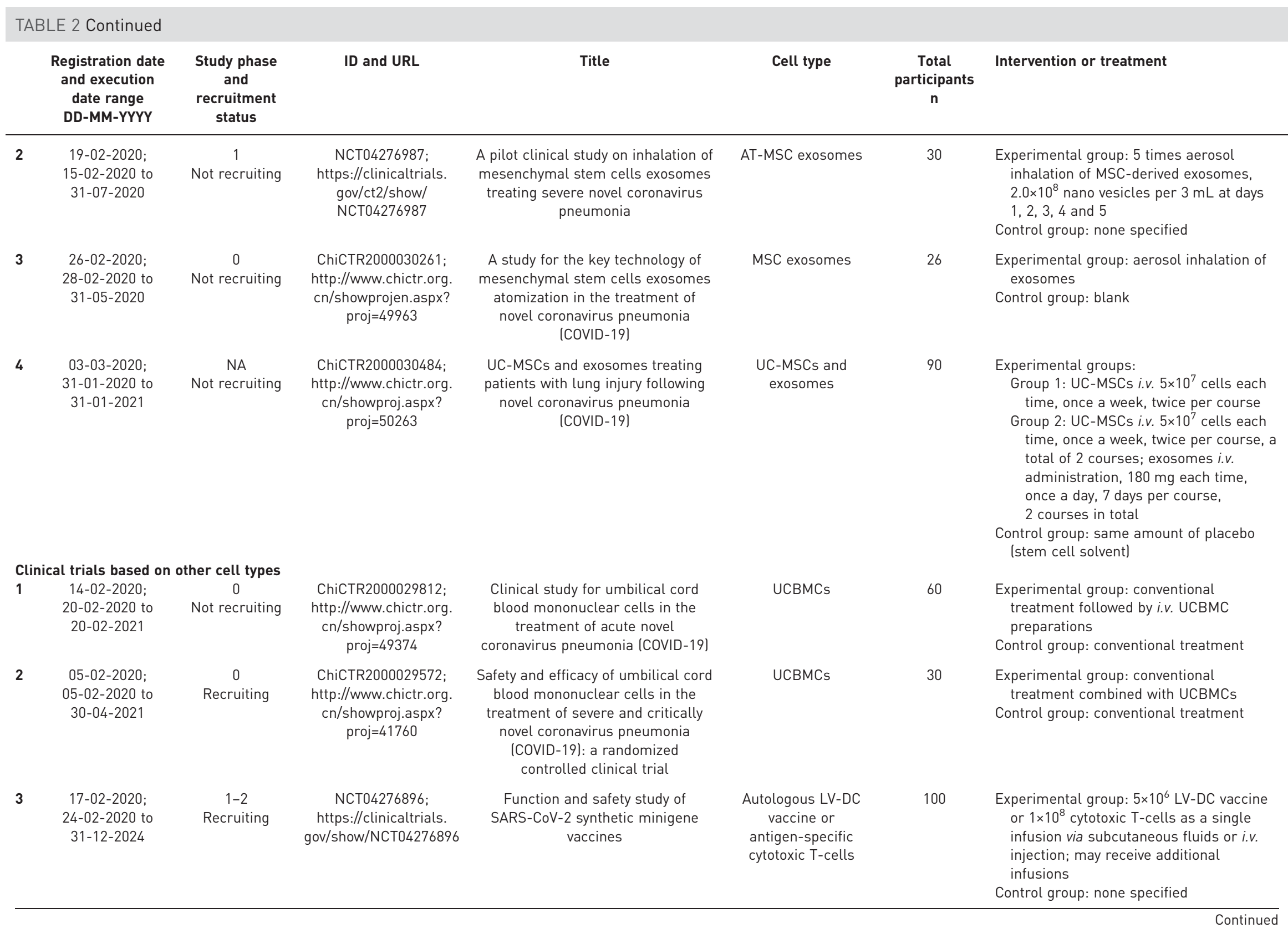




\begin{tabular}{|c|c|c|c|c|c|c|c|}
\hline & $\begin{array}{l}\text { Registration date } \\
\text { and execution } \\
\text { date range } \\
\text { DD-MM-YYYY }\end{array}$ & $\begin{array}{l}\text { Study phase } \\
\text { and } \\
\text { recruitment } \\
\text { status }\end{array}$ & ID and URL & Title & Cell type & $\begin{array}{c}\text { Total } \\
\text { participants } \\
n\end{array}$ & Intervention or treatment \\
\hline 4 & $\begin{array}{c}13-02-2020 \\
20-02-2020 \text { to } \\
30-12-2020\end{array}$ & $\begin{array}{c}1 \\
\text { Recruiting }\end{array}$ & $\begin{array}{c}\text { NCT04280224; } \\
\text { https://clinicaltrials. } \\
\text { gov/show/NCT04280224 }\end{array}$ & $\begin{array}{l}\text { NK cells treatment for novel } \\
\text { coronavirus pneumonia }\end{array}$ & NK cells & 30 & $\begin{array}{l}\text { Experimental group: conventional } \\
\text { treatment plus twice a week of NK cells } \\
\left(0.1-2 \times 10^{7} \mathrm{NK} \text { cells } \cdot \mathrm{kg}^{-1} \text { body weight) }\right. \\
\text { Control group: conventional treatment }\end{array}$ \\
\hline 5 & $\begin{array}{c}06-03-2020 \\
10-04-2020 \text { to } \\
10-11-2020\end{array}$ & $\begin{array}{c}2 \\
\text { Not recruiting }\end{array}$ & $\begin{array}{l}\text { NCT04299152; } \\
\text { https://clinicaltrials. } \\
\text { gov/ct2/show/ } \\
\text { NCT04299152 }\end{array}$ & $\begin{array}{l}\text { Clinical application of stem cell } \\
\text { educator therapy for the treatment } \\
\text { of viral inflammation caused by } \\
\text { severe acute respiratory syndrome } \\
\text { coronavirus } 2 \text { (SARS-CoV-2) }\end{array}$ & CB-SCs & 20 & $\begin{array}{l}\text { Experimental group: combination product: } \\
\text { stem cell educator-treated mononuclear } \\
\text { cells apheresis therapy circulates a } \\
\text { patient's blood through a blood cell } \\
\text { separator, briefly cocultures the } \\
\text { patient's immune cells with adherent } \\
\text { CB-SCs in vitro, and returns the } \\
\text { "educated" autologous immune cells to } \\
\text { the patient's circulation } \\
\text { Control group: conventional treatment: } \\
\text { regular treatments, only addressing } \\
\text { their symptoms, such as reducing fever } \\
\text { and cough }\end{array}$ \\
\hline 6 & $\begin{array}{c}28-02-2020 \\
01-03-2020 \text { to } \\
17-02-2021\end{array}$ & $\begin{array}{c}0 \\
\text { Not recruiting }\end{array}$ & $\begin{array}{l}\text { ChiCTR2000030088; } \\
\text { http://www.chictr.org. } \\
\text { cn/showproj.aspx? } \\
\text { proj=49779 }\end{array}$ & $\begin{array}{l}\text { Clinical trial for umbilical cord } \\
\text { blood CIK and NK cells in the } \\
\text { treatment of mild and general } \\
\text { patients infected with novel } \\
\text { coronavirus pneumonia (COVID-19) }\end{array}$ & CIK and NK cells & 90 & $\begin{array}{l}\text { Experimental groups: } \\
\text { CIK group: UCB CIK cells } \\
\left(1.6 \times 10^{8} \text { cells } \cdot \mathrm{kg}^{-1}\right) \text { injected twice } \\
\text { every other day } \\
\text { NK group: UCB NK cells } \\
\left(1.6 \times 10^{8} \text { cells } \cdot \mathrm{kg}^{-1}\right) \text { injected twice } \\
\text { every other day } \\
\text { Control group: conventional therapy }\end{array}$ \\
\hline
\end{tabular}

MSCs: mesenchymal stem (stromal) cells; i.v.: intravenous; UCB: umbilical cord blood; NK: natural killer; MenSCs: mesenchymal stem cells derived from menstrual fluid; UC: umbilical cord; CM: conditioned medium; AT: adipose tissue; UCBMCs: umbilical cord blood-derived mononuclear cells; LV-DC: lentivirus dendritic cell; CB-SCs: cord blood stem cells; CIK: cytokine-induced killer. 
stay and ventilator-free days. We also strongly advocate for utilising clinical samples, obtained as part of appropriate clinical care or for monitoring adverse events following cell administration, to obtain mechanistic information including but not limited to analyses of circulating pro- and anti-inflammatory mediators and inflammatory cell populations. Given the rapidity of the COVID-19 spread and the increasing numbers of cell-based therapy investigations, a central coordinating centre to expedite congruent trial design and appropriate data dissemination would be of significant benefit.

A further significant issue is which COVID-19 patient population to target and when to initiate MSC administration. Critically ill patients with ARDS requiring supportive measures including intubation and mechanical ventilation are a logical population to target. Appreciating that there are other potential therapeutic approaches being considered in this population, it would seem reasonable to target these patients as soon as possible following intubation and mechanical ventilation. Arguments can also be made for targeting severely infected patients with currently recognised risk factors such as increased age, diabetes and/or cardiovascular disease, who are at potentially higher risk for clinical deterioration. In this instance, emerging data on clinical and laboratory indications, such as level of oxygenation, changes in oxygenation and elevations in indicators of systemic cytokine storm, may be criteria for initiating MSC administration. As these indicators are evolving, we advocate a broad-minded approach for considering when to consider MSC use. Whether moderate or mild disease patients should be part of clinical investigation remains less clear. The available pre-clinical data and the safety data from clinical trials in non-viral ARDS best support potential use. As it is too early to tell whether there will be any downstream respiratory effects in COVID-19 ARDS survivors, this seems a less urgent population to target. Similarly, targeting recovering mild or moderately affected patients to counter as yet unknown downstream effects on the lungs also seems to be a less urgent consideration. Overall, to date there has been a limited understanding of the pathogenesis of COVID-19, which currently hinders the development of an optimal study design.

Whether to utilise genetically modified MSCs is unclear at present. This in part reflects the current lack of understanding as to which action, i.e. secreted mediator constitutively or inducibly produced by MSCs, may be most effective in SARS-CoV-2 respiratory infections. This also reflects the lack of clear evidence at present as to whether any other potentially therapeutic agent will have proven efficacy, for example an IL-6 or IL-1 receptor antagonist that the MSCs could be engineered to produce. This may change rapidly as current treatment investigations evolve, involving these and other agents. Furthermore, as genetically modified cell products require more lengthy regulatory approval, this may not be a strategy of choice to face the current outbreak.

\section{Challenges and perspectives}

The global pandemic of COVID-19 respiratory infection has prompted urgent need for novel therapies. Clinical and basic science investigators need to take the lead by promoting and adhering to rigorously designed investigations logically based on available pre-clinical data. The limited available data regarding MSC administration in pre-clinical respiratory disease injury models and current understanding of potential mechanisms of MSC actions in lung injury models can be cautiously and carefully utilised to support rationally designed and conducted clinical investigations. However, more pre-clinical data are necessary, particularly in models of coronavirus-induced lung injuries. While compassionate use of unproven MSC-based therapies may be contemplated in different circumstances, we urge that, whenever possible, this takes place in the larger context of a clinical investigation. Since the original writing of this review, a number of academic and industry-sponsored trials of MSC-based investigations have been initiated globally in addition to the ones in China reviewed here. We urge all of these to uphold the highest standards for rational and appropriately designed investigations. Only in these ways can a rational evidence-based platform for potential therapeutic use of cell-based therapies be developed.

We must also take strong stance against the stem cell clinic industry, which has already begun to offer unproven therapies for COVID-19. The International Society for Cell and Gene Therapy, the International Society for Stem Cell Research and a number of other professional and scientific organisations have taken leadership positions in this area [54-56]. The potential for abuse is high, given the desperate circumstances of the COVID-19 pandemic, and unauthorised use of unproven therapies is a clear danger.

Acknowledgements: We acknowledge Monica Kurte (University of Los Andes, Santiago, Chile) for performing the bioinformatic analysis of the GEO database.

Conflict of interest: M. Khoury reports grants from CONICYT (FONDEF 2016, IT16110084), during the conduct of the study; stipend received from Cells for Cells, outside the submitted work; has patents WO2014135924A1 pending, WO2017064670A2 pending, WO2017064672A1 pending and WO/2019/051623 pending; and is CSO of Cells for Cells, a University spin-off developing therapies for osteoarthritis, pulpitis and cardiac failure, and Regenero, a consortium for Chilean regenerative medicine (public and private funding), for skin ulcer and Lupus. J. Cuenca reports grants from CONICYT (FONDEF 2016, IT16I10084), during the conduct of the study; stipend received from Cells for Cells, outside 
the submitted work; and is a research scientist for Cells for Cells, a University spin-off developing therapies for osteoarthritis, pulpitis and cardiac failure, and Regenero, a consortium for Chilean regenerative medicine (public and private funding), for skin ulcer and Lupus. F.F. Cruz has nothing to disclose. F.E. Figueroa has a patent WO/2019/ 051623 pending and is a board member of Cells for Cells, as the director of the programme of translational cell therapy at Universidad de los Andes, the academic institution that originated the Consorcio Corfo Regenero and the Cells for Cells biotechnological spin-off. P.R.M. Rocco has nothing to disclose. D.J. Weiss reports grants from NIH, Cystic Fibrosis Foundation and US Department of Defense, outside the submitted work.

Support statement: This work was partially supported by grants from Agencia Nacional de Investigación y Desarrollo, ANID, formerly known as CONICYT (FONDEF 2016, IT16I10084). Funding information for this article has been deposited with the Crossref Funder Registry.

\section{References}

1 Zhu N, Zhang D, Wang W, et al. A novel coronavirus from patients with pneumonia in China, 2019. $N$ Engl J Med 2020; 382: 727-733.

2 Sheahan TP, Sims AC, Leist SR, et al. Comparative therapeutic efficacy of remdesivir and combination lopinavir, ritonavir, and interferon beta against MERS-CoV. Nat Commun 2020; 11: 222.

3 Mehta P, McAuley DF, Brown M, et al. COVID-19: consider cytokine storm syndromes and immunosuppression. Lancet 2020; 395: 1033-1034.

4 Armitage J, Tan DBA, Troedson R, et al. Mesenchymal stromal cell infusion modulates systemic immunological responses in stable COPD patients: a phase I pilot study. Eur Respir J 2018; 51: 1702369.

5 Galipeau J, Sensébé L. Mesenchymal stromal cells: clinical challenges and therapeutic opportunities. Cell Stem Cell 2018; 22: 824-833

6 Lee RH, Pulin AA, Seo MJ, et al. Intravenous hMSCs improve myocardial infarction in mice because cells embolized in lung are activated to secrete the anti-inflammatory protein TSG-6. Cell Stem Cell 2009; 5: 54-63.

7 Krasnodembskaya A, Song Y, Fang X, et al. Antibacterial effect of human mesenchymal stem cells is mediated in part from secretion of the antimicrobial peptide LL-37. Stem Cells 2010; 28: 2229-2238.

$8 \mathrm{Hu}$ S, Park J, Liu A, et al. Mesenchymal stem cell microvesicles restore protein permeability across primary cultures of injured human lung microvascular endothelial cells. Stem Cells Transl Med 2018; 7: 615-624.

9 Laffey JG, Matthay MA. Fifty years of research in ARDS. Cell-based therapy for acute respiratory distress syndrome. Biology and potential therapeutic value. Am J Respir Crit Care Med 2017; 196: 266-273.

10 Court AC, Le-Gatt A, Luz-Crawford P, et al. Mitochondrial transfer from MSCs to T cells induces Treg differentiation and restricts inflammatory response. EMBO Rep 2020; 21: e48052.

11 Islam MN, Das SR, Emin MT, et al. Mitochondrial transfer from bone-marrow-derived stromal cells to pulmonary alveoli protects against acute lung injury. Nat Med 2012; 18: 759-765.

12 Liotta F, Angeli R, Cosmi L, et al. Toll-like receptors 3 and 4 are expressed by human bone marrow-derived mesenchymal stem cells and can inhibit their T-cell modulatory activity by impairing Notch signaling. Stem Cells 2008; 26: 279-289.

13 Waterman RS, Tomchuck SL, Henkle SL, et al. A new mesenchymal stem cell (MSC) paradigm: polarization into a pro-inflammatory MSC1 or an immunosuppressive MSC2 phenotype. PLoS One 2010; 5: e10088.

14 Lee JW, Krasnodembskaya A, McKenna DH, et al. Therapeutic effects of human mesenchymal stem cells in ex vivo human lungs injured with live bacteria. Am J Respir Crit Care Med 2013; 187: 751-760.

15 Monsel A, Zhu YG, Gennai S, et al. Therapeutic effects of human mesenchymal stem cell-derived microvesicles in severe pneumonia in mice. Am J Respir Crit Care Med 2015; 192: 324-336.

16 Li Y, Xu J, Shi W, et al. Mesenchymal stromal cell treatment prevents H9N2 avian influenza virus-induced acute lung injury in mice. Stem Cell Res Ther 2016; 7: 159.

17 Polchert D, Sobinsky J, Douglas G, et al. IFN-gamma activation of mesenchymal stem cells for treatment and prevention of graft versus host disease. Eur J Immunol 2008; 38: 1745-1755.

18 Malcherek G, Jin N, Hückelhoven AG, et al. Mesenchymal stromal cells inhibit proliferation of virus-specific $\mathrm{CD}^{+}$T cells. Leukemia 2014; 28: 2388-2394.

19 Liu X, Feng T, Gong T, et al. Human umbilical cord mesenchymal stem cells inhibit the function of allogeneic

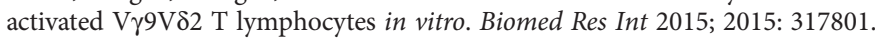

20 Karlsson H, Samarasinghe S, Ball LM, et al. Mesenchymal stem cells exert differential effects on alloantigen and virus-specific T-cell responses. Blood 2008; 112: 532-541.

21 Wu X, Dao Thi VL, Huang Y, et al. Intrinsic immunity shapes viral resistance of stem cells. Cell 2018; 172: 423-438.

22 Bailey CC, Zhong G, Huang IC, et al. IFITM-family proteins: the cell's first line of antiviral defense. Annu Rev Virol 2014; 1: 261-283.

23 Thanunchai M, Hongeng S, Thitithanyanont A. Mesenchymal stromal cells and viral infection. Stem Cells Int 2015; 2015: 860950.

24 Khatri M, O’Brien TD, Goyal SM, et al. Isolation and characterization of chicken lung mesenchymal stromal cells and their susceptibility to avian influenza virus. Dev Comp Immunol 2010; 34: 474-479.

25 Khatri M, Saif YM. Influenza virus infects bone marrow mesenchymal stromal cells in vitro: implications for bone marrow transplantation. Cell Transplant 2013; 22: 461-468.

26 Thanunchai M, Kanrai P, Wiboon-Ut S, et al. Tropism of avian influenza A (H5N1) virus to mesenchymal stem cells and CD34 ${ }^{+}$hematopoietic stem cells. PLoS One 2013; 8: e81805.

27 Cheung MB, Sampayo-Escobar V, Green R, et al. Respiratory syncytial virus-infected mesenchymal stem cells regulate immunity via interferon beta and indoleamine-2,3-dioxygenase. PLoS One 2016; 11: e0163709.

28 Hoffmann M, Kleine-Weber H, Krüger N, et al. The novel coronavirus 2019 (2019-nCoV) uses the SARS-coronavirus receptor ACE2 and the cellular protease TMPRSS2 for entry into target cells. bioRxiv 2020 preprint [https://doi.org/10.1101/2020.01.31.929042].

$29 \mathrm{Xu} \mathrm{H}$, Zhong L, Deng J, et al. High expression of ACE2 receptor of 2019-nCoV on the epithelial cells of oral mucosa. Int J Oral Sci 2020; 12: 8 . 
30 Ziegler C, Allon SJ, Nyquist SK, et al. SARS-CoV-2 receptor ACE2 is an interferon-stimulated gene in human airway epithelial cells and is enriched in specific cell subsets across tissues. SSRN 2020; preprint [https://doi.org/10. 2139/ssrn.3555145].

31 Han J, Li Y, Li Y. Strategies to enhance mesenchymal stem cell-based therapies for acute respiratory distress syndrome. Stem Cells Int 2019; 2019: 5432134.

32 Li X, Molina-Molina M, Abdul-Hafez A, et al. Angiotensin converting enzyme-2 is protective but downregulated in human and experimental lung fibrosis. Am J Physiol Lung Cell Mol Physiol 2008; 295: L178-L185.

$33 \mathrm{He} \mathrm{H}$, Liu L, Chen Q, et al. Mesenchymal stem cells overexpressing angiotensin-converting enzyme 2 rescue lipopolysaccharide-induced lung injury. Cell Transplant 2015; 24: 1699-1715.

34 He HL, Liu L, Chen QH, et al. MSCs modified with ACE2 restore endothelial function following LPS challenge by inhibiting the activation of RAS. J Cell Physiol 2015; 230: 691-701.

35 Cruz FF, Weiss DJ, Rocco PR. Prospects and progress in cell therapy for acute respiratory distress syndrome. Expert Opin Biol Ther 2016; 16: 1353-1360.

36 McIntyre LA, Moher D, Fergusson DA, et al. Efficacy of mesenchymal stromal cell therapy for acute lung injury in preclinical animal models: a systematic review. PLoS One 2016; 11: e0147170.

37 Darwish I, Banner D, Mubareka S, et al. Mesenchymal stromal (stem) cell therapy fails to improve outcomes in experimental severe influenza. PLoS One 2013; 8: e71761.

38 Gotts JE, Abbott J, Matthay MA. Influenza causes prolonged disruption of the alveolar-capillary barrier in mice unresponsive to mesenchymal stem cell therapy. Am J Physiol Lung Cell Mol Physiol 2014; 307: L395-L406.

39 Chan MC, Kuok DI, Leung CY, et al. Human mesenchymal stromal cells reduce influenza A H5N1-associated acute lung injury in vitro and in vivo. Proc Natl Acad Sci USA 2016; 113: 3621-3626.

40 Khatri M, Richardson LA, Meulia T. Mesenchymal stem cell-derived extracellular vesicles attenuate influenza virus-induced acute lung injury in a pig model. Stem Cell Res Ther 2018; 9: 17.

41 Loy H, Kuok DIT, Hui KPY, et al. Therapeutic implications of human umbilical cord mesenchymal stromal cells in attenuating influenza A(H5N1) virus-associated acute lung injury. J Infect Dis 2019; 219: 186-196.

42 Abreu SC, Weiss DJ, Rocco PR. Extracellular vesicles derived from mesenchymal stromal cells: a therapeutic option in respiratory diseases? Stem Cell Res Ther 2016; 7: 53.

43 Phelps J, Sanati-Nezhad A, Ungrin M, et al. Bioprocessing of mesenchymal stem cells and their derivatives: toward cell-free therapeutics. Stem Cells Int 2018; 2018: 9415367.

44 Frieman MB, Chen J, Morrison TE, et al. SARS-CoV pathogenesis is regulated by a STAT1 dependent but a type I, II and III interferon receptor independent mechanism. PLoS Pathog 2010; 6: e1000849.

45 Bao L, Deng W, Huang B, et al. The pathogenicity of 2019 novel coronavirus in hACE2 transgenic mice. bioRxiv 2020; preprint [https://doi.org/10.1101/2020.02.07.939389].

46 Bao L, Deng W, Gao H, et al. Reinfection could not occur in SARS-CoV-2 infected rhesus macaques. bioRxiv 2020; preprint [https://doi.org/10.1101/2020.03.13.990226].

47 Leng Z, Zhu R, Hou W, et al. Transplantation of ACE2 ${ }^{-}$mesenchymal stem cells improves the outcome of patients with COVID-19 pneumonia. Aging Dis 2020; 11: 216-228.

48 Chen J, Hu C, Chen L, et al. Clinical study of mesenchymal stem cell treating acute respiratory distress syndrome induced by epidemic Influenza A (H7N9) infection, a hint for COVID-19 treatment. Engineering 2020; in press [https://doi.org/10.1016/j.eng.2020.02.006].

49 Jin YH, Cai L, Cheng ZS, et al. A rapid advice guideline for the diagnosis and treatment of 2019 novel coronavirus (2019-nCoV) infected pneumonia (standard version). Mil Med Res 2020; 7: 4.

50 Matthay MA, Calfee CS, Zhuo H, et al. Treatment with allogeneic mesenchymal stromal cells for moderate to severe acute respiratory distress syndrome (START study): a randomised phase 2a safety trial. Lancet Respir Med 2019; 7: 154-162.

51 World Health Organization. Guidance for managing ethical issues in infectious disease outbreaks. Geneva, World Health Organization, 2016. Available from: https://apps.who.int/iris/handle/10665/250580

52 Athersys Inc. Athersys announces positive results from its exploratory clinical study of multistem cell therapy for treatment of acute respiratory distress syndrome (ARDS). www.athersys.com/investors/press-releases/press-releasedetails/2019/Athersys-Announces-Positive-Results-From-Its-Exploratory-Clinical-Study-of-MultiStem-Cell-Therapyfor-Treatment-of-Acute-Respiratory-Distress-Syndrome-ARDS/default.aspx Date last updated: 23 January 2019.

53 Keusch G, McAdam K, Cuff PA, et al., eds. Integrating Clinical Research into Epidemic Response: The Ebola Experience. Washington, National Academies Press, 2017.

54 International Society for Cell and Gene Therapy (ISCT). ISCT releases statement on unproven stem cell treatments for COVID-19. https://isctglobal.org/news/494824/ISCT-Releases-Statement-on-Unproven-Stem-CellTreatments-for-COVID-19.htm Date last updated and accessed: 20 March 2020.

55 EuroStemCell. Stem cells and COVID-19. www.eurostemcell.org/stem-cells-and-covid-19 Date last updated: 12 March 2020. Date last accessed: 18 March 2020.

56 International Society for Stem Cell Research (ISSCR). ISSCR statement regarding the marketing of unproven stem cell treatments for COVID-19. www.isscr.org/news-publicationsss/isscr-news-articles/article-listing/2020/03/06/ isscr-statement-regarding-the-marketing-of-unproven-stem-cell-treatments-for-covid-19 Date last updated: 6 March 2020. Date last accessed: 18 March 2020. 